\title{
United we stand: big roles for small RNA gene clusters
}

\author{
BRICE FELDEN ${ }^{1,2}$ and LUC PAILLARD ${ }^{2,3}$ \\ ${ }^{1}$ Inserm U835 Biochimie Pharmaceutique, Rennes University, F-35043 Rennes, France \\ ${ }^{2}$ Biosit, Rennes University/Université Européenne de Bretagne, F-35043 Rennes, France \\ ${ }^{3}$ Centre National de la Recherche Scientifique UMR 6290, Institut de Génétique et Développement de Rennes, F-35043 Rennes, France
}

\begin{abstract}
Prokaryotes and eukaryotes evolved relatively similar RNA-based molecular mechanisms to fight potentially deleterious nucleic acids coming from phages, transposons, or viruses. Short RNAs guide effector complexes toward their targets to be silenced or eliminated. These short immunity RNAs are transcribed from clustered loci. Unexpectedly and strikingly, bacterial and eukaryotic immunity RNA clusters share substantial functional and mechanistic resemblances in fighting nucleic acid intruders.
\end{abstract}

Keywords: CRISPR; RNA evolution; RNA gene cluster; regulatory RNA

Regulatory small RNAs (sRNAs) are essential for protecting living cells against potentially harmful DNA challenges. They are found in all domains of life, and the parallels between their functions and mechanistic properties in eukaryotes and prokaryotes are striking. Their shared key role is to specify the targets of their associated effectors. During the interference phase, the sRNAs guide ribonucleoproteic complexes to the proper nucleic acid targets by base-pairing. This guidance capacity is surprisingly conserved in prokaryotes and eukaryotes (Fig. 1), so it may be a leftover from an ancestral RNA world where the RNA was responsible both for the interaction specificity and the biochemical fate of the targets.

The sRNAs of each domain differ in their partners and biological consequences. In prokaryotes, CRISPR RNAs (clustered regularly interspaced short palindromic repeat RNAs, crRNAs) guide Cas proteins to foreign DNA to trigger endonucleolytic cleavage, thus preventing bacteriophage infections and plasmid invasions (Wiedenheft et al. 2012). In eukaryotes, PIWI-interacting RNAs (piRNAs) guide complexes that include PIWI, a member of the Argonaute (Ago) superfamily of proteins, to transposon DNA. This induces gene silencing through epigenetic modifications, and hence represses transposition. In eukaryotes also, short, doublestranded RNAs (small interfering RNAs, siRNAs) associate into a complex also containing Ago, and target it to a complementary RNA to trigger its degradation. If the siRNA comes from a double-stranded viral RNA, this mechanism contributes to host antiviral defenses (Axtell et al. 2011; Czech and Hannon 2016). Ago proteins are the central hubs of sRNA-

\footnotetext{
Corresponding authors: brice.felden@univ-rennes1.fr, luc.paillard@ univ-rennes1.fr

Article is online at http://www.rnajournal.org/cgi/doi/10.1261/rna. 058891.116 .
}

mediated silencing devices in eukaryotes, but recent evidence also highlights the involvement of prokaryotic Ago in protecting bacterial genomes against foreign, and possibly invasive, genomic elements such as plasmids (Olovnikov et al. 2013; Swarts et al. 2014). The molecular mechanisms that control sRNA association with the effector complex differ between crRNAs, piRNAs, and siRNAs. The prokaryotic crRNAs interact by pairing with another RNA, tracrRNA, which tethers them to Cas proteins. There is no known eukaryotic equivalent for tracrRNA, and how a transcribed RNA is recognized as a piRNA to be processed and linked to PIWI is currently not well understood. Meanwhile, a double-strand conformation triggers siRNA recognition by Ago. Thanks to this limited structural requirement, the siRNA pathway is used in reverse genetics to silence gene expression by RNA interference.

Dissimilarities aside, eukaryotic and prokaryotic sRNAs do both act as guide RNAs. Another resemblance is their shared genomic organization as clusters. Gene clusters are associations of genes expressing similar macromolecules with shared functions. Most investigations have focused on protein gene clusters (e.g., the vertebrate hox genes), but sRNAs are also frequently produced from clusters. piRNA cluster sequences are poorly conserved throughout evolution, despite the strong prevalence of the clustered organization itself, and they share extensive sequence conservation with nonfunctional transposon fragments. This suggests that they may have formed by aggregating captured transposons sequentially (Czech and Hannon 2016), thereby expanding cluster

(C) 2017 Felden and Paillard This article is distributed exclusively by the RNA Society for the first 12 months after the full-issue publication date (see http:// rnajournal.cshlp.org/site/misc/terms.xhtml). After 12 months, it is available under a Creative Commons License (Attribution-NonCommercial 4.0 International), as described at http://creativecommons.org/licenses/by-nc/4.0/. 


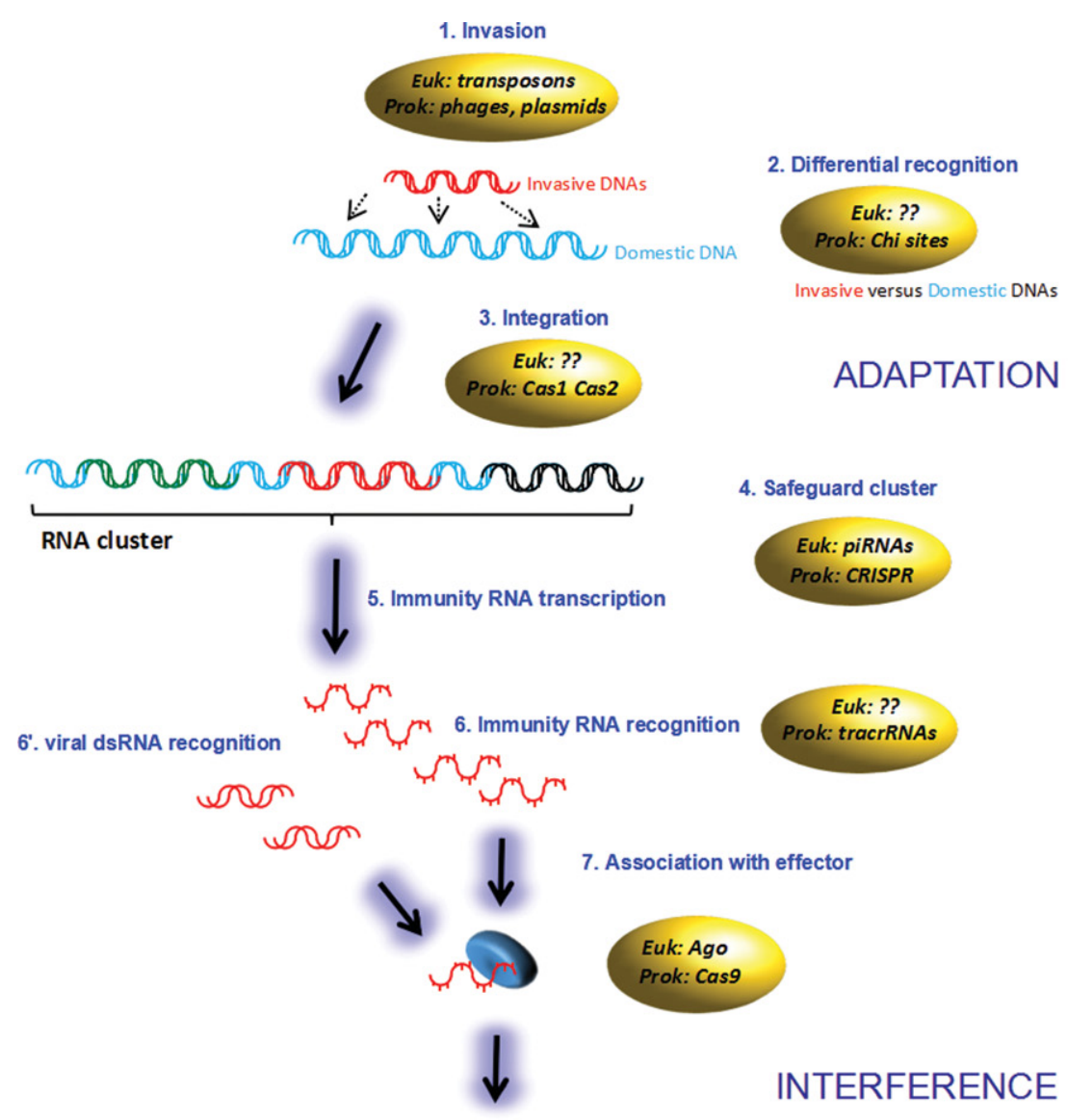

8. RNA-mediated guidance to target nucleic acids
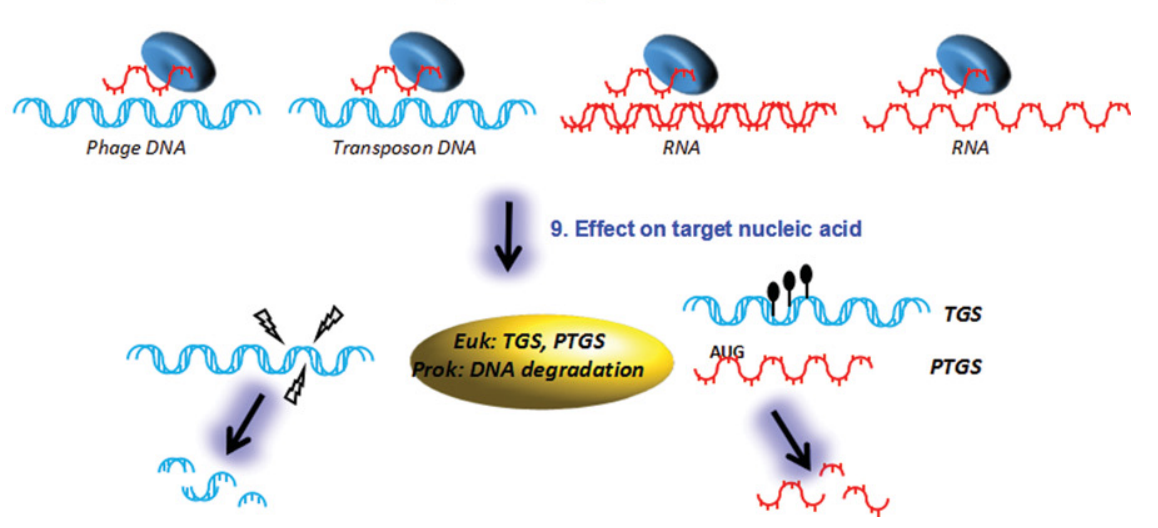

FIGURE 1. Comparison showing the close resemblance of prokaryotic and eukaryotic immunity cluster RNA. Molecular defense against DNA intruders in the two domains was subdivided into nine distinct steps. During the initial adaptation phase, invasive DNAs (phages, plasmids, or transposons) are inserted into specialized genomic clusters. During the following interference phase, RNAs transcribed from these clusters associate into ribonucleoproteic complexes (yellow ovals) to target the invasive phage DNA for destruction in prokaryotes, or the transposon DNA for transcriptional gene silencing (TGS) in eukaryotes. sRNAs transcribed from clustered miRNA genes, as well as viral siRNAs, regulate post-transcriptional gene expression by translational inhibition and/or RNA degradation (post-transcriptional gene silencing, PTGS).

complexity. It is unknown whether this appropriation is due to the random insertion of active transposons into a preexisting piRNA cluster, or if there is a direct capture mechanism. siRNAs are exogenous (viral infections or exper- imentally introduced nucleic acid sequences), and there are no documented siRNA gene clusters. However, siRNAs substantially resemble another class of eukaryotic sRNAs, the microRNAs (miRNAs). miRNAs differ from siRNAs by their origins, as they are all genomeencoded. Cellular miRNAs have antiviral functions in mammalian cells (Pedersen et al. 2007), but their major function is to regulate endogenous gene expression. Most often in animals, they imperfectly pair with their target RNAs, and the primary outcome of miRNA-mediated regulations is translational repression. Interestingly, miRNA genes are clustered. miRNA gene clusters may have come about due to the cotranscriptional recruitment of miRNA processing enzymes, which facilitates the emergence of new sRNAs near existing ones (Axtell et al. 2011). In addition, miRNA genes within a cluster share sequence conservation, suggesting that these clusters have expanded by local duplications. miRNA gene clusters may be subjected to duplications and to the subsequent appearance of new miRNA genes as a consequence of genomic imprinting. Indeed, miRNA clusters are enriched in imprinted regions (Girardot et al. 2012). However, the driving forces for eukaryotic miRNA cluster formation remain essentially elusive.

The molecular events that direct prokaryotic crRNA cluster dynamics are far better understood (Fig. 1). During adaptation, bacteria and archaea acquire new sequences from foreign DNA, and once integrated these spacers serve as templates for crRNA synthesis. Three recent studies explained foreign DNA acquisition preference and how spacer invaders are captured. Spacer acquisition is replication-dependent, and replication forks are more frequent on multicopy plasmids than on the chromosome. In addition, Chi (crossover hotspot instigator) sites, highly repeated octamer sequences on the bacterial chromosome, negatively impact spacer acquisition. Together, these observations explain how non-self DNA is preferred over the self for spacer acquisition (Levy et al. 2015). Two structural studies revealed how the Cas1-Cas2 complex acts as an integrase (Nuñez et al. 2015; Wang et al. 2015). This 
conserved complex binds a protospacer sequence to catalyze spacer acquisition. These recent works showed how protospacer length is predetermined, selected, processed into a spacer and integrated into the bacterial genome. These studies also showed that the Cas1-Cas2 complex has a similar structure to the eukaryotic transposases used by transposons to integrate into chromosomes.

The comparison of eukaryotic and prokaryotic sRNA clusters raises many questions. Are similar mechanisms at play in both domains? Can the growing knowledge gleaned from bacteria help us to understand eukaryotic cluster dynamics? What selection pressure induced such a peculiar genomic organization throughout evolution? Bringing together genes involved in similar functions is often seen to ease their coregulation. Furthermore, piRNA clusters have specific epigenetic profiles (Le Thomas et al. 2014) that may help to tag the transcribed RNAs as being piRNAs. Assembling sRNA genes into functional immunity clusters is probably a way to improve the efficiency of defenses against DNA intruders in cells from all domains of life.

\section{REFERENCES}

Axtell MJ, Westholm JO, Lai EC. 2011. Vive la différence: biogenesis and evolution of microRNAs in plants and animals. Genome Biol 12: 221.
Czech B, Hannon GJ. 2016. One loop to rule them all: the Ping-Pong cycle and piRNA-guided silencing. Trends Biochem Sci 41: 324337.

Girardot M, Cavaillé J, Feil R. 2012. Small regulatory RNAs controlled by genomic imprinting and their contribution to human disease. Epigenetics 7: 1341-1348.

Le Thomas A, Marinov GK, Aravin AA. 2014. A transgenerational process defines piRNA biogenesis in Drosophila virilis. Cell Rep 8: $1617-1623$.

Levy A, Goren MG, Yosef I, Auster O, Manor M, Amitai G, Edgar R, Qimron U, Sorek R. 2015. CRISPR adaptation biases explain preference for acquisition of foreign DNA. Nature 520: 505-510.

Nuñez JK, Harrington LB, Kranzusch PJ, Engelman AN, Doudna JA. 2015. Foreign DNA capture during CRISPR-Cas adaptive immunity. Nature 527: 535-538.

Olovnikov I, Chan K, Sachidanandam R, Newman DK, Aravin AA. 2013. Bacterial argonaute samples the transcriptome to identify foreign DNA. Mol Cell 51: 594-605.

Pedersen IM, Cheng G, Wieland S, Volinia S, Croce CM, Chisari FV, David M. 2007. Interferon modulation of cellular microRNAs as an antiviral mechanism. Nature 449: 919-922.

Swarts DC, Jore MM, Westra ER, Zhu Y, Janssen JH, Snijders AP, Wang Y, Patel DJ, Berenguer J, Brouns SJ, et al. 2014. DNA-guided DNA interference by a prokaryotic Argonaute. Nature 507: 258261.

Wang J, Li J, Zhao H, Sheng G, Wang M, Yin M, Wang Y. 2015. Structural and mechanistic basis of PAM-dependent spacer acquisition in CRISPR-Cas systems. Cell 163: 840-853.

Wiedenheft B, Sternberg SH, Doudna JA. 2012. RNA-guided genetic silencing systems in bacteria and archaea. Nature 482: 331-338. 

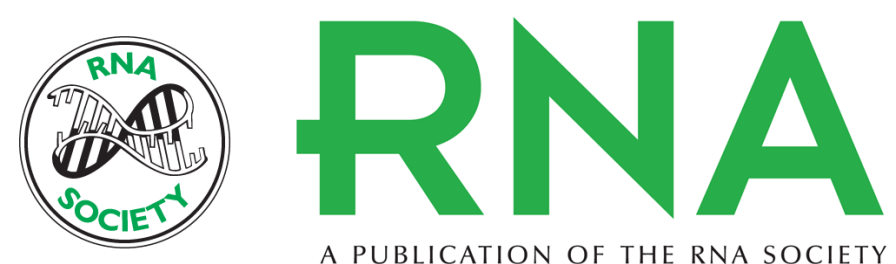

A PUBLICATION OF THE RNA SOCIETY

\section{United we stand: big roles for small RNA gene clusters}

Brice Felden and Luc Paillard

RNA 2017 23: 131-133 originally published online November 23, 2016

Access the most recent version at doi:10.1261/rna.058891.116

Creative This article is distributed exclusively by the RNA Society for the first 12 months after the

Commons full-issue publication date (see http://rnajournal.cshlp.org/site/misc/terms.xhtml). After 12

License months, it is available under a Creative Commons License (Attribution-NonCommercial

4.0 International), as described at http://creativecommons.org/licenses/by-nc/4.0/.

Email Alerting Receive free email alerts when new articles cite this article - sign up in the box at the Service top right corner of the article or click here.

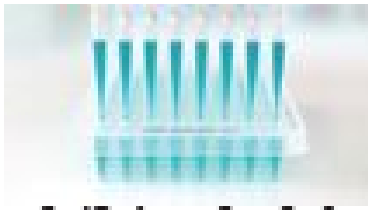

Providing Precise Solutions for your research.

To subscribe to RNA go to:

http://rnajournal.cshlp.org/subscriptions

(C) 2017 Felden and Paillard; Published by Cold Spring Harbor Laboratory Press for the RNA Society 